Geliş Tarihi: 31.07.2019 Doi: 10.18026/cbayarsos.599333 Kabul Tarihi: 09.09.2019

\title{
MACARLARIN GÖZÜYLE MİLLİ MÜCADELE ve TÜRK İMAJI
}

\section{Müjdat KARAGÜLMEZ1}

\begin{abstract}
Öz
Türkler ve Macarlar arasındaki temaslar, tarihin çok eski dönemlerinde başlamıştır. Bu iki millet, Osmanlı'nın Balkanlar'da ve Avrupa'da ilerlediği dönemde düşman olsalar da, XIX. yüzyıldan itibaren iki millet arasında kardeşlik duygularının geliştiği görülmüştür. I. Dünya Savaşı'nda iyi bir seviyeye çıkan Türk-Macar ilişkileri, Anadolu'da verilen Milli Mücadele döneminde de dostane şekilde devam etmiştir. Türklerin, Mustafa Kemal önderliğinde Anadolu'da verdikleri Milli Mücadele, kardeş Macar halkı tarafından yakından takip edilmiştir. Trianon Antlaşması ile topraklarının 3/2'sini kaybeden Macarlar, Türklerin bu var oluş mücadelesini emperyalist güçlere karşı savaşan milletlere örnek olarak göstermişler ve Milli Mücadele'ye büyük bir sempati ile yaklaşmışlardır. Basın yayın yoluyla Milli Mücadele'ye destek olan Macarlar, Avrupa'da Türklerin davasının haklılığını ortaya koyan bir ses olmuşlardır. Mustafa Kemal'den eșsiz bir devlet adamı ve komutan olarak bahseden Macar kaynaklarl, bağımsızlığını geri kazanmak için her şeyini ortaya koyan Türk halkının azmini Avrupa'da kanıtlaması bakımından da önem taşımaktadır.

Bu çalışmada, Türklerin büyük bir özveri göstererek Milli Mücadele'yi nasıl başarıya ulaştırdıkları Macarların gözüyle aktarılacaktır. Burada özellikle, Macar Turancılarının Türklerin haklı davası olarak gördükleri Milli Mücadele'ye verdikleri destekten, Milli Mücadele'nin Macar basınındaki yankılarından ve konunun Macar Elçilik raporlarında nasıl işlendiğinden bahsedilecektir.
\end{abstract}

Anahtar Kelimeler: Milli Mücadele, Macarlar, Macar Turanciları, Macar Basinı.

\section{NATIONAL STRUGGLE FROM THE EYES OF THE HUNGARIANS AND TURKISH IMAGE}

\begin{abstract}
The contacts between the Turks and the Hungarians began in ancient times. Although these two nations were enemies in the period when the Ottomans advanced in the Balkans and in Europe, from the 19th century onwards, the feelings of brotherhood developed between
\end{abstract}

1 Öğr. Gör. Dr., Milli Savunma Üniversitesi, mujdat.karagulmez@hotmail.com ORCID: 0000-0002-9169-7004 
the two nations. Turkish-Hungarian relations, which reached a good level in the First World War, continued in a friendly way during the National Struggle in Anatolia as well. The National Struggle that Turks gave in Anatolia under the leadership of Mustafa Kemal, was closely followed by the Hungarian people. The Hungarians who lost 3/2 of their territory through the Trianon Agreement have shown the Turks struggle against this existence as an example of the nations fighting against the imperialist powers and have approached the National Struggle with great sympathy. The Hungarians who supported the National Struggle through the press, were a voice in Europe that revealed the right of the Turks. Hungarian sources, referring to Mustafa Kemal as a unique statesman and commander, are important in terms of proving the determination of the Turkish people in Europe, who put forth everything to regain their independence.

In this paper, it will be conveyed from the eyes of the Hungarians how Turks succeeded in achieving the National Struggle by showing great devotion. Here especially, it will be mentioned the support of the Hungarian Turanians to the National Struggle, which they see as the rightful cause of the Turks, the repercussion of the National Struggle in the Hungarian press and how the issue is handled in the Hungarian Embassy reports.

Keywords: National Struggle, Hungarians, Turks, Hungarian Turanians, Turan Journal, Hungarian Press.

\section{Giriş}

Türkiye ile Macaristan arasındaki ilişkiler tarihin çok eski dönemlerine kadar gitmektedir. Macarlar, 896 yılında Karpat Havzası'na yerleşip bu toprakları yurt edinmelerine kadar çeşitli Türk kavimleri ile iç içe yaşamıştır. Bu iç içe yaşam nedeniyle Macarlar Türklük özellikleri kazanmış ${ }^{1}$ ve Türkler gibi yaşayan bir kavim haline gelmiştir. ${ }^{2}$ Türk-Macar temasları, Mohaç Meydan Muharebesi (1526) sonrasinda Osmanlı Devleti'nin Macaristan topraklarına hâkim olduğu dönemde de hız kesmeden devam etmiştir. Bu dönemde Türkler, Macarların dillerine ve kültürel

\footnotetext{
${ }^{1}$ Melek Çolak, "Atatürk Döneminde Kültürel, Siyasi ve Ekonomik Bakımdan TürkMacar İlişkileri (1919-1938)", Muğla Üniversitesi SBE Dergisi, C.1, S.2, (Güz 2000), s.61-62.

2 Şerif Baştav, "Tarihte Türk-Macar Münasebetleri ve Macar-Türk Akrabalığı”, Tarih ve Toplum, S.215, Kasım 2001, s.60-61.
} 
değerlerine dokunmamış $\quad$ ve saygı $_{\text {göstermișlerdir. }}{ }^{3}$ Osmanlı Devleti'nin Macar topraklarına hâkim olduğu bu dönemde Macarlar ve Türkler arasındaki ilişkiler sonucunda bahçecilik, deri işlemeciliği, süsleme sanatları, bakırcılık, çömlekçilik ve müzik ile edebiyat alanlarında etkileşim meydana gelmiş ve pek çok Türk kültürel ögesi Macarlar arasında kendini kabul ettirmiștir. ${ }^{4}$ Osmanlı Devleti'nden sonra Macar topraklarının büyük çoğunluğu Avusturya İmparatorluğu'nun denetimine girmiştir. Bu dönem Türk-Macar ilişkileri için yeni bir dönem olmuştur. ${ }^{5}$ Macar milliyetçileri, Avusturya İmparatorluğu'na karşı Imre Thököly' ${ }^{6}$, II. Ferenc Rákóczi ${ }^{7}$ ve Lajos Kossuth ${ }^{8}$ önderliğinde tarihte $3 \mathrm{kez}$ özgürlük mücadelesi verseler de bu mücadeleler başarıya ulaşamamıştır. Vermiş oldukları mücadelede başarısız olan Macar özgürlük savaşçılarının yardımına Osmanlı Devleti koşmuş ve Macar savaşçllara kucak açmıştır. ${ }^{9}$ Osmanlı Devleti'nin gösterdiği bu misafirperverlik Macar halkının kalbinde derin bir iz bırakmıştır. Macar mültecileri İznik, Tekirdağ ve Kütahya gibi yerlerde Türklerin derin ehemmiyeti altında yaşamış ve

\footnotetext{
3 Yücel Namal, Türk-Macar İlişkileri, İskenderiye Yayınları, İstanbul 2009, s.32; İki millet arasındaki kültürel etkileșim dile de yansımıștır. Macaristan'da Osmanlı hâkimiyeti döneminde Türk kültürünün Macar dilindeki etkisi için bkz. Zsuzsa Kakuk, "Türk Kültür Etkisinin Macar Dilindeki Yansımaları", IX. Türk Tarih Kongresi, TTK, C. III, (21-25 Eylül 1981), Ankara 1989, s.1223-1225.

${ }^{4}$ Mária Nyíri, "Türklüğün Bir Kolu Olarak Macarlar veya Türk-Macar KardeșliğiAkrabalığı ve Tarihsel İlișkiler Üzerine", Çeşitli Türk Toplumları Arasındaki Dil ve Kültür Bağı Sempozyumu, (5-6 Ekim 1990), Kıbrıs Araștırma ve Yayın Merkezi, Lefkoşa, s.9.

5 Gábor Fodor, "Macar Gözüyle Osmanlı İmparatorluğu ve Türkiye (1850-1940)", Güney-Doğu Araştırmaları Dergisi, Y.2014-1, S.25, s.79.

6 Imre Töhökly için bkz. Nesrin Gürkan, "Tarihte Macar Misafirlerimiz", 2023, S.59, Haziran 2006, s.52-57.

7 II. Ferenc Rákóczi için bkz. Türk-Macar Münasebetleri Işığı Altında II. Ferenc Rákóczi ve Macar Mülteciler Sempozyumu (31 Mayıs-3 Haziran 1976), İstanbul Üniversitesi Edebiyat Fakültesi, İstanbul 1976; Mikes Kelemen, Osmanlı'da Bir Macar Konuk Prens Rákóczi ve Kelemen Mikes'in Türkiye Mektupları, Çev. Edit Tasnadi, Aksoy Yayıncllık, İstanbul 1999.

8 Lajos Kossuth için bkz. Edit Tasnádi, "18.-19. Yüzyllda Osmanlı'da Macar Mülteciler", Tarih ve Toplum, C.36, S.215, (Kasım 2001), s.327-332; Ebubekir Sofuoğlu, "Abdülmecit ve Macar Mülteciler", Tarih ve Toplum, S.215, (Kasım 2001), s.279-302.

9 Türkiye'de kendilerine sığınma hakkı verilen Macar mültecilerin hayat hikâyeleri için bkz. Róbert Hermann-András Joó-Kálman Mészáros-István Seres, Török menedékjogot kapott magyar emigránsok rövid életrajzi összefoglalója (Türkiye'de Kendilerine Sığınma Hakkın Tanınan Macar Mültecilerinin Hayatlarından Özetler), Türk-Macar Dostluk Derneği, 2010.
} 
içlerinden bazıları Türk topraklarında yaşamlarını yitirmiştir. Bu nedenle Rodosto (Tekirdağ) ve Kütahya her zaman Macar ziyaretçiler için "Mekke" olarak anılmıştır. ${ }^{10}$

XIX. yüzyıl sonu ve XX. yüzyılın başlarında Türk-Macar ilişkileri daha da gelişmiştir. Asya kökenli bir kavim olarak Avrupalılar tarafından dışlanan Macarlar, kendi öz benliklerini ortaya çıkarmak için dil ve tarih araştırmalarına önem vermişlerdir. Bu araştırmalar neticesinde Macaristan'da Türkoloji ve Turancılık ortaya çıkmıştır. Türkoloji ve Turancıllğın ortaya çıkardığı bulgular, Türkleri ve Macarları birbirine daha da yakınlaştırmıştır. ${ }^{11}$ Bunun yanında, XX. yüzyılın başlarında iki milletin yolu bir kez daha ortak çıarları nedeniyle kesişmiştir. Avusturya-Macaristan İmparatorluğu12 I. Dünya Savaşı'nda Osmanlı Devleti ile aynı safta yer almış; Almanya, Avusturya-Macaristan ve Osmanlı arasında 2 Ağustos 1914 tarihinde bir ittifak antlaşması imzalamıștır. ${ }^{13}$ I. Dünya Savaşı'nda ortak düşmanlara karşı aynı safta yer almaları, siyasi, iktisadi ve kültürel alanda Türkleri ve Macarları yakınlaştırmış ve dolayısıyla da Türk-Macar dostluğunu güçlendirmiştir. ${ }^{14}$ Nitekim I. Dünya Savaşı sona erdiğinde Osmanlı Devleti ve AvusturyaMacaristan İmparatorluğu'nun dâhil olduğu İttifak güçleri savaştan yenilgi ile ayrılmış ${ }^{15}$; savaş sonrasında Macaristan ile savaşın galip devletleri arasında Trianon Barış Antlaşması16 imzalanırken, Osmanlı

\footnotetext{
10 “Török-Magyar Barátság (Türk-Macar Dostluğu)", Magyar Külpolitika, XIV. évfolyam, 10. szám, 1933-Október, Budapest, s.11.

11 Melek Çolak, "Macaristan'da Türkoloji, Turancılık ve Türk Dünyası (XIX. Yüzyıldan XX. Yüzyıla)", 15. Uluslararası Türk Dünyası Sosyal Bilimler Kongresi, Tebliğler Kitabı, (Moldova 2017), s.461-462.

12 Macaristan, Avusturya ile 1876 yllında ikili bir yönetim modeli çerçevesinde birleșmiştir. Birleşmeden sonra İmparatorluğun ismi Avusturya-Macaristan İmparatorluğu olmuștur.

13 Emre Saral, Türkiye-Macaristan İlişsileri (1920-1945), Basılmamış Doktora Tezi, Hacettepe Üniversitesi Atatürk İlke ve İnkılapları Enstitüsü, Ankara 2016, s.22.

${ }^{14}$ Çolak, "Atatürk Döneminde Kültürel, Siyasi ve Ekonomik...", s.63.

${ }^{15}$ H. Berke Dilan, Siyasi Tarih 1914-1939, Alfa Yayınları, İstanbul 1998, s.39.

16 Savaşın galip devletleri, savaşın yenik devletleri ile hangi şartlarda barıș anlaşmaları imzalayacaklarına dair Paris'te bir konferans toplamışlardı. Macaristan'ın Paris Barış Konferansı'na gönderdiği heyet özellikle Macarların çoğunlukta olduğu bölgelerde referandum yapılması konusunda Milletler Cemiyeti'ne önemli ölçüde güvenmekteydi. Nitekim Konferans Macarların istediği gibi sonuçlanmayacaktır. Tüm çabalarına rağmen Trianon Antlaşması'nı imzalamak zorunda kalacak olan Macarlar, tarihi Macar Krallı̆̆ topraklarının önemli bir kısmını, birçoğu I. Dünya Savaşı'ndan sonra kurulan komşu ülkelere bırakmak
} 
Devleti ile Sevr Barıș Antlaşması imzalanmıştır. Sevr, Mustafa Kemal ve silah arkadaşları tarafından Anadolu'da verilen Milli Mücadele nedeniyle yürürlüğe girmemiştir. Macarların, Milli Mücadele sürecince Türklere büyük destekleri olmuştur. Özellikle mazlum milletlerin var oluş mücadelesine Türkleri örnek gösteren Macarlar, Türklerin savaşını kendileri için "parlayan bir umut yıldızı" olarak görmüşler ve bu nedenle Milli Mücadeleyi desteklemişlerdir. Türk Milli Mücadele'sinin başarıya ulaşması Macarlar tarafından coşkuyla karșlanmıștır. ${ }^{17}$

\section{Macarların Gözüyle Milli Mücadele ve Türk İmajı}

30 Ekim 1918 tarihinde imzalanan Mondros Mütarekesi'nden sonra Anadolu'nun işgal edilmeye başlanması, tüm Avrupa'da olduğu gibi Macarlar tarafından da yakından takip edilen meselelerden birisi olmuştur. İşgallere karşı Türk halkının vermiş olduğu tepki, bir var oluş mücadelesi olarak Macarlar tarafından özenle işlenmiştir. Milli Mücadele süresince Macarların yakın desteğini hisseden Türkler, Avrupa'da her șeyden çok Macarlara güvenmişler ve Macarlar da manevi olarak hiçbir millete olmadığı kadar Türklere yakınlık duymuşlardır.18 $\mathrm{Bu}$ pozitif ortamda Macarlar tarafından Milli Mücadele hakkında çok sayıda yazı kaleme alınmıș ve Türk yanlısı bir duruş sergilenmiștir.

Macarlar, Türkler için I. Dünya Savaşı'nı bitiren Mondros Mütarekesi'nin ardından Anadolu'nun çeşitli bölgelerinin öncelikle İngilizler ve Fransızlar tarafından işgal edildiğini ve Mondros'un maddeleri gereğince Türk askerlerinin silah bırakmasının ardından Ermenilerin de büyük bir istila hareketine giriştiklerini yazmışlardır. Asıl Türk direnişinin İzmir'in işgalinden sonra başladığını belirten Macarlar, Yunan işgalinin sadece Türklerin elit tabakasında değil aynı zamanda tüm ulusta yayılan bir protestonun başlamasına neden olduğunu vurgulamıștır. I. Dünya Savaşı'nın ardından Arapların yoğunlukta olduğu toprakların kaybedilmesinin Türklerde büyük bir yıkıma neden olmadığını söyleyen Macarlar, Anadolu'nun işgalinin ise Türklüğün parçalanması ve sürgün edilmesi anlamına gelmesi

zorunda kalacaktır. Trianon Antlașması ve anlaşma sonrasındaki Macar sınırları için bkz. Zoltán Palotás, A Trianoni Határok (Trianon Sinirlarl), Interedition, Budapest 1990.

17 Çolak, a.g.m., s.65-66.

18 Gyula Németh, "Törökök és Magyarok (Türkler ve Macarlar)", Törörök és Magyarok I, Budapest 1990, s.26. 
nedeniyle büyük bir uyanışa neden olduğunu ifade etmişlerdir. Ayrıca, tüm Anadolu'nun bu hissiyatı yaşamasının direniş hareketini güçlendirdiğini de vurgulamışlardır. ${ }^{19}$

Osmanlı Sultanı Vahdettin, I. Dünya Savaşı sona ererken hangi şartlarda olursa olsun barış anlaşması yapmayı planlamaktaydı. Nitekim Sultan Vahdettin, savaş sonrasında Osmanlı'ya sunulan barıș anlaşmasının ağır maddelerini görse de, bu anlaşmayı kabul etmek zorunda kalmıştı. Ona göre, İngilizler geçmişte Osmanlı ile pek çok kez ittifak yapmıştı ve İngilizlerin dostluğu bu sebeple önemliydi. ${ }^{20}$ Macar kaynaklarında da Vahdettin'in ülkenin işgaline karşı tavrı ve Milli Mücadele'ye karşı duruşu hakkında bazı yorumlar yapılmıştır. Macarlara göre, Osmanlı Sultanı bu durumdan acı çekmekle birlikte, İtilaf Devletleri ile barış anlaşması imzalanmasına hazırdı.21

Macarlara göre, Milli Mücadele'nin başkahramanı Mustafa Kemal'di. Mustafa Kemal, Samsun'a çlkmasıyla birlikte Milli Mücadele'yi başlatmıştı ve bu andan itibaren de Rus Bolşevik ihtilalciler ile diplomatik ilişkiler kurmanın yollarını aramaya başlamıștır. Mustafa Kemal, Bolșeviklerle diplomatik olarak bir bağ kurarak Anadolu'daki işgalci devletlere karşı bir denge sağlayabilirdi. Mustafa Kemal'in bu siyasetini Sovyetler olumlu anlamda karşılamıştı. Macarlara göre, Mustafa Kemal Batı'ya karşı akıllıca taktikler uygulamıştır. Mustafa Kemal'in Bolşeviklere yaklaşmasında, bağımsızlık hareketinin komünist bir yapıya bürünmesi gibi fikir yoktur ve bu politikasının asıl nedeni İngiliz hükümetinin özellikle Lyoyd George'nun anlayışsız güç politikası, nefret söylemleri ve Anadolu'daki işgallerdir.22

Macarlar ve Macar basını Milli Mücadele'ye ve Mustafa Kemal'e özel bir ilgi göstermiş ve Türklerin Anadolu'daki var oluş mücadelesinin Avrupa'daki savunucusu olmuşlardır. ${ }^{23}$ Ayrıca, Milli Mücadele'nin Macaristan'daki en büyük destekçilerinden birisi Macar

\footnotetext{
${ }^{19}$ Egeresi Zoltán, "A török nemzetépítés Atatürk korában (Atatürk döneminde Türk Ulus İnşası)” Világtörténet-Tanulmáynok, (2013):1, s.130.

20 Gotthard Jaeschke, Kurtuluş Savaşı ile İlgili İngiliz Belgeleri, Türk Tarih Kurumu, Ankara 2011, s.1-5.

21 Zoltán, a.g.m., s.130.

22 István Flesch, Atatürk És Kora, Musztafa Kemál Atatürk Függetlenségi Háborúja És Kormányzása (Atatürk ve Dönemi, Mustafa Kemal'in Bağımsızlı Mücadelesi ve Yönetimi), Corvina Kiadó, 2004, s.207.

23 "A beteg ember (Hasta Adam)", Magyarság, III. Évi, 202.(510.) Szám, 6 Szerda Szepmtember 1922, s.1.
} 
Turancıları $^{24}$ olmuştur. Türkleri kardeș bir halk olarak gören Macar Turancıları, Anadolu'daki isyanı ve milli direnişi desteklemişledir. Macar Turancllarının Milli Mücadele'ye verdikleri en büyük destek, Türklerin milli davasının haklılığını basın-yayın yoluyla Avrupa'da ispat etmeye çalışmaları olmuştur. Bunun için, Avrupa kamuoyunu Milli Mücadele'nin haklılığı hususunda ikna etmeye çalışmışlardır. ${ }^{25}$ Macar Turancılarından Andor Medriczky, Mustafa Kemal'in Türk ulusunun kurtarıcısı olarak Milli Mücadele'nin başına geçmesini kadere bağlamıştır. Ona göre, I. Dünya Savaşı'nın sona ermesinin ardından kader, Mustafa Kemal'i Türk ulusunun özgürlüğü için izlemesi gereken bir yola sokmuştur. Bununla birlikte yine, kaderin Mustafa Kemal'e büyük imkânlar ve yeni bir görev verdiğini ve kaderin çizmiş olduğu bu yolu baştan aşağıya kendisinin yaratması gerektiğini ifade etmiştir.26

Medriczky'e göre, Mustafa Kemal Samsun'a çlkmasının ardından hemen genel bir durum değerlendirmesi yapmış ve öncelikle yakın illerdeki yetkili subay ve komutanlarla temas kurmaya çalışmıştır. Bu süreç içerisinde Mustafa Kemal, ülkenin Doğu kesiminde bağımsız bir Ermeni devleti27 kurulma planının

24 1910'da kurulan Macar Turán Cemiyeti, resmi anlamda ve etkin bir şekilde Türkiye-Macaristan ilişkilerine hizmet vermiş ve Milli Mücadele'yi desteklemiştir. Bkz. Horvát Béla, "A Turáni Eszme és a Török-Magyar Kapcsolatok az Utolsó Évszázadban (Turan Düşüncesi ve Son Yüzyılda Türk-Macar İlişkileri)", Turán, XXII. Évfolyam, 6. Szám, 1939, s.119; Macar Turancıları ve Atatürk hakkında detaylı bilgi için ayrıca bkz. Melek Çolak, Macar Turancıları ve Atatürk(Macar Kaynaklarına Göre), Türk Yurdu, C.31, S.21, (Ekim 2010), s.77-87.

25 Ağustos 1921 yılında kurulan Turan Haber Ajansı'nın kurulması Türk Milli Mücadele'sinin haklılığı düşüncenin yayılmasında önemli bir rol oynamıștır. Turan Haber Ajansı'nın faaliyetleri ile ilgili 1935 yılında çıkan bir yazıda, Türklerin kahramanca mücadelesinin Avrupa basını tarafından Avrupa devletlerinin ekonomik çıkarları nedeniyle iftira ve yalan kampanyalar ile karalanmaya çalışıldığı ve basın terörünün estirildiği ifade edilmiştir. Eklenerek, Avrupa basınının ısrarla sürdürdügü tek yanlı ve kasıtlı politikası nedeniyle böyle bir derginin çıkarılmasına olan ihtiyaçtan bahsedilmiștir. Bkz. Tarık Demirkan, Macar Turancıları, Tarih Vakfı Yurt Yayınları, İstanbul 2000, s.49-50.

26 Andor Medriczky, "Kemal Atatürk a had vezér az államférfi és az ember (Bir Kamutan, Devlet adamı ve İnsan Olarak Kemal Atatürk)", Turán, 1937-38, VIIX.szám., XX-XXI. Évfolyam, s.125.

271910 yllında Budapește'de kurulan Turán Cemiyeti, Anadolu'da yaşanan Ermeni meselesi hakkında kesin bir tavır sergileyerek Türklerin yanında olmuştur. Turan Cemiyeti, Ermeni iddiaları karşısında Türkiye'ye iftira kampanyası bașlatıldığını ve yabancı gazetelerin yayınladıkları yazılarla dünya kamuoyunu Türklere karşı harekete geçirmeye çalıştıkları yazılmıştır. Turan dergisinde çıkan bir yazıda Macar 
yaratmış olduğu tehlikeden de gayet iyi bir şekilde haberdardı. Mustafa Kemal, kısa bir zaman sonra şunu görmüştü; İstanbul Hükümeti'nin ihmal ettiği, uzun senelerdir süren savaşlar yüzünden bıkmış, ekonomik ve kültürel hayat şartları arasında yorgun düşmüş ve derin bir uykuda olan millet uyandırılmalıydı..28

Macar kaynaklarında, Anadolu'nun işgalinden sonra Kuva-i Milliye birliklerinin düşmana karşı sınırlı bir mücadele olanağının olduğu yazılırken Mustafa Kemal'in direnişin lideri olması ile halkı örgütlemeye başladığı belirtilmiştir. Mustafa Kemal'in ve Ona inananların katılımıyla gerçekleşen Erzurum ve Sivas kongrelerinin, düşmana karşı direnişin ilanı olduğu vurgulanırken bu kongrelerin programlarında Osmanlı-Müslüman kimliğinin ön planda olduğu, aynı zamanda Mustafa Kemal'in söylemine göre, halkın çıkarlarının korunmasına ve halkın temsil edildiğine de dikkat çekilmiştir. ${ }^{29}$

Yine Macarlara göre, Anadolu'daki işgalci devletlerin arasındaki en büyük rol İngiltere'ye aitti ve İngiltere, Yunan ordusunu kendi çıkarları için kullanmıştı. Ayrıca, Sultan'ın Antant devletlerinin kontrolü altında olduğu ve Mustafa Kemal öncülüğünde kurulan Ankara Hükümeti'nin, Türklüğün bağımsızlığına giden yolda İngiltere ve Yunanistan başta olmak üzere işgalci devletlere karşı büyük bir savaş verdiği yazılmıştır. ${ }^{30}$

Milli Mücadele'nin hazırlı safhasına bakıldığında, Anadolu'nun asker ve donanım bakımından oldukça zayıf olduğu gerçeği ön plana çıkmaktadır. Fakat bu olumsuz durum Mustafa Kemal'in kurtuluşa olan inancını asla zayıflatmamıștır. Mondros'un maddeleri gereğince orduları dağıtılmış ve İtilaf Devletlerinin kontrolünde olan bir ortamda yine umut vardır. Macar Turancıları, Anadolu'daki bu durumu gayet iyi şekilde açıklamışlardır. Onlara göre vaziyet şu şekildedir: ${ }^{31}$

"Anadolu'da ordu yoktu, donanım yoktu. Sultan ise İngilizlerin baskısı altındaydı ve bu nedenle İstanbul tamamen düşmana hizmet etmekteydi. Ayrıca bir millet de yoktu, onun yerine iradesi bile olmadan her şeye katlanmış bir halk vardı. Bu şartlar etrafında düşmana karşı

Turancıları, dünya basınında yer alan bu yalan haberleri yayımlamaları üzerine kendi basınına seslenerek telkinlerde bulunmuştur. Bkz. Demirkan, a.g.e., s.56.

${ }^{28}$ Medriczky, a.g.m., s.126.

${ }^{29}$ Zoltán, a.g.m., s.131.

30 Vukovári Gábor, "A török külpolitika alapjai és változásai (Türk Dış Politikasının Temelleri ve Değişimleri )”, Külügyi Szemle, 2. Évfolyam, 4. Szám-1975, s.40.

${ }^{31}$ Medriczky, a.g.m., 127-128. 
hareket edebilmek için öncelikle ülkeyi ve halkı bilgilendirmek gerekliydi. Türk halkı barış istiyordu, başka bir şey istemiyordu, o kadar bitkindi ki belki de bu yüzden düşman işgali canlarını acıtamıyordu. Ya da işgallerden korkuyorlardı, kan dökülmesinden ve bastırlmaktan korkuyorlardı. Daha ne istediklerini, nasll istediklerini ve neden istediklerini bilmiyorlard. Öyleyse ilk önce silkelenmeleri, Türk halkına gidilmesi gereken yolun gösterilmesi gerekliydi. Bunu da eşsiz, özel, 39 yaşındaki komutanla gerçekleștirecekti."

Turán Dergisi'nde çıkan yazıda; "Mustafa Kemal Erzurum Kongresi toplandığında çevresindeki politikacılar ve subayları da dikkatle izledi ve büyük milli görevi yürütebilecek ve sonuca ulaştırabilecek tek kişinin kendisi olduğunu gördü" șeklinde bir ifadeye yer verilmiştir. Macar Turancılara göre, Mustafa Kemal'in görevi çok riskliydi ve tek başınaydı, fakat gerekli olan idareye sahip oluşuyla, yeteneğiyle ve kutsal inancıyla böyle bir riski göze almıștı. Nitekim çevresinde, Mustafa Kemal'den daha tecrübeli daha rütbeli olanlar vardı. Ayrıca aile, servet, rütbe ve otoriteye de sahiptiler ki büyük bir cesaret gösterip bu riski göze alabilirlerdi. İște, Mustafa Kemal farkını burada ortaya koyacaktı. Anadolu hareketinin ciddiyetini fark eden Sultan, Mustafa Kemal'i görevden aldığında Mustafa Kemal hâlâ sakinliğini koruyabilmişti ve rütbesi alındıktan sonra basit bir vatandaş olarak mücadelesine devam etmiști. Onlara göre, Mustafa Kemal adım adım mücadelesini inşa etmişti. Öncelikle asıl hedefe yönelik ulusal bir farkındalık oluşturdu. Sonrasında ise Milli Mücadele'nin başarıya ulaşmasının zor olduğunu düşünen askeri muhalefetin başarı umudunu uyandırdı ve sonrasında askeri başarı geldi. Askerlerine de umut aşılamıştı. ${ }^{32}$

Macar kaynaklarında, Milli Mücadele yıllarındaki Türk dış politikasının temel amacının, Türk halkının ulusal kurtuluş ve bağımsızlık mücadelesini gerçekleştirmek olduğu yer almıştır. Yine, Milli Mücadele dönemi Türk hükümetinin dış politika faaliyetlerinin, Türk halkının ulusal çıkarlarını koruma, ulusal bağımsızlığı gerçekleștirme, emperyalist müdahaleye karşı yurdu savunma ve genel barışa, özellikle de Sovyetler Birliği ile dostluğu geliştirme ve güçlendirme üzerine kurduğu belirtilmiştir. Bu dönemde Anadolu'yu işgal eden yabancı devletlerin ise, Mondros Mütarekesi ve Sevr Barış Antlaşması ile Türkleri İngiltere'nin kontrolü altında ortadan kaldırmak ve Orta Doğu'nun çıkarlarına hizmet eden bir araç haline

32 Medriczky, a.g.m., 127-128. 
getirmeyi amaçladıkları ifade edilmiştir. Bunun devamında ise asıl planın, ülkenin ortasında, Ankara civarında, bugünkü Türkiye'nin yaklaşık üçte birine sıkıștırılmış bir devlet bırakmak olduğu belirtilmiştir. ${ }^{33}$

Milli Mücadele'de Mustafa Kemal'in yanı sıra diğer subaylarında aktif șekilde katkıda bulundukları Macar kaynaklarında yer almıştır. Kaynaklarda, Milli Mücadele'nin başarıya ulaşmasında Mustafa Kemal'in yanında Rauf Orbay, Ali Fuat Cebesoy ve Refet Bele gibi deneyimli subayların varlığına dikkat çekilirken Kazım Karabekir'in Mondros'un maddeleri gereğince dağıtılması gereken, fakat dağılmadan kalan düzenli ordusunun büyük desteği olduğu belirtilmiştir. Ayrıca Milli Mücadele'de Türkiye'nin şansının ise, büyük ihtiyacın olduğu bu vaziyette çok sayıda iyi yetişmiş subayın orduda gönüllü olarak hizmet etmesi olarak gösterilmiştir.34

Yine, Milli Mücadele'ye büyük önem veren Macar Turancılarına göre, 1919-1922 yılları arasında, varlığı ve hayatta kalması tehlike altında olan Türk milleti hayranlık uyandırıcı bir özgürlük mücadelesi vermiştir. Milli Mücadele ile başlayan ve Lozan Antlaşması'nın imzalanmasıyla da devam eden bu süreç, Macar milleti tarafından sıcak bir sempatiyle eşlik edilmiştir. Macarlar, baştan sona başarıyı hak eden büyük kardeş ülkeye böyle bir hissiyatla yaklaşmıştır. ${ }^{35}$

Turán Dergisi'nde çıkan yazıların yanı sıra Macar basını da, Türklerin vermiş oldukları Milli Mücadele'den övgüyle bahsetmişlerdir. Milli Mücadele ile ilgili bir yazıda; "Türkiye, soylu ahlakı, halkının kırılmaz, yıkıcı özelliği, muhteşem vatanseverliğiyle gerçek ışığıyla parladı. Türkiye kendi istikbali için, Sevr Antlaşması'nın utanç verici hükümlerini vermiş olduğu mücadele sonucunda yok saydı ve yeni bir barış anlaşması yapılması için evlatlarını cesaretlendiren tek ülkeydi" şeklinde bir ifadeye yer verilmiştir. ${ }^{36}$

Diğer taraftan, Çanakkale Savaşlarındaki üstün başarısı, Muş ve Bitlis'in kurtarılmasındaki rolü, Çanakkale Savaşı sırasında kendisiyle röportaj yapılması ve bu röportajın Tasvir-i Efkâr'da yayınlanması Mustafa Kemal'in halk arasinda tanınan bir komutan

\footnotetext{
33 Vukovári, a.g.m., s.39-40.

34 Fleschs, a.g.e., $146-147$.

35 Horvát, a.g.m., s.119.

36"török barátaink (Türk Kardeșlerimiz)”, Budapesti Hírlap, XLXIII. Évfolyam, 186. Szám, 17 Augusztus 1928, Budapest, s.1.
} 
olmasında etkili olmuştu. Bunun yanında Mustafa Kemal'in de kurucuları arasında olduğu Minber Gazetesi'nde çıkan yazıları Onun tanıtımını yapması bakımından önemliydi. ${ }^{37}$ Mustafa Kemal'in, Anadolu'ya geçmeden ünü çoktan yayılmıştı ve Macarlar da Mustafa Kemal'den haberdardı. Milli Mücadele'den bahseden Macar gazetelerinin haberlerindeki ana aktörün Mustafa Kemal olarak ön plana çıktığı görülürken gazetelerin Onu, milliyetçi direniş lideri olarak sayfalarına taşıdıkları görülmüştür. ${ }^{38}$

Milli Mücadele'nin aksiyon safhası sona ererken Türk ordusunun Yunanlılara karşı elde ettiği başarılar ve sonrasındaki müzakereler süreci Macar kamuoyunda sevinçle karşılanmıştır. Bu arada, Antant devletleri ve Osmanlı Devleti arasında Sevr Barıș Antlaşması'nın imzalanması Macarların oldukça dikkatini çekmiştir. Onlara göre, barış antlaşması bölgedeki gergin siyasi durumu daha da ağırlaştırmış ve bu olaylar sonucunda Mustafa Kemal'in etkinliği ve Türk ordusunun direnişi daha da güçlenmiștir. Bunlara, Türklerin Ermenilere karşı büyük bir zafer elde ettiği de eklenirken Doğu'daki birliklerin Batı'daki Yunan ilerleyişinin durdurulması için bu cepheye kaydırıldığı aktarılmıştır. ${ }^{39}$ Batı cephesindeki askeri başarının artmasiyla Mustafa Kemal'in Yunan taarruzunu tamamen ortadan kaldırmaya karar verdiği ve Büyük Taarruz ile Yunan kuvvetlerini İzmir'e kadar sürüp burada düşman askerlerini tamamen yenilgiye uğratmak amacında olduğu ifade edilmiştir. Savaş alanındaki başarıların diplomatik alandaki bașarıları da beraberinde getirdiğini söyleyen Macar gazeteleri, Mustafa Kemal'in yeni diplomatik başarılar elde ettiğini de yazmışlardır. Örneğin, Fransızlarla yapılan Ankara Antlaşması'nın İngiltere'nin Mezopotamya'daki çıkarlarına zarar verdiği ve İngiliz-Fransız tarafları arasında büyük bir anlaşmazlığın çıkmasına neden olduğu belirtilmiştir. ${ }^{40}$

Magyarság Gazetesi'nin 1922 yılına ait bazı yazılarında Macarların Türklere ve Milli Mücadele'ye karşı duyduğu sempatiyi görmek mümkündür. Bu gazete, kısa zaman içinde yapmış olduğu

\footnotetext{
37 Yücel Özkaya, "Mustafa Kemal Paşa Anadolu'da”, Mücadele Tarihi-Makaleler-, Haz. Berna Türkdoğan, Atatürk Araștırma Merkezi, s.138-139.

38 Sevgi Can Yağcı Aksel, "Macar Basınında Türkiye:"Küçük Asya"nın Büyük Direniși(1920-1923)", İlef Dergisi, 2018, 5(2), Sonbahar, s.62.

39 Bíró Gábor, "A török függetlenségi háború a magyar sajtó tükrében (Macar Basını Ișığında Türk Bağımsızlık Mücadelesi)", Acta Universitatis Szegediensis, Acta historica, 126. tom, 2007, s.196-197.

${ }^{40}$ Bíró, a.g.m., s.199.
} 
haberler ile halkın sevgisini kazanmış ve Türk çıkarlarının savunucusu olmuştur. ${ }^{41}$ Gazetenin 1922 yılının Eylül ayında çıkan bir yazısında "Beteg Ember(Hasta adam)" başlığı altında Milli Mücadele ve Türklerin azmi detaylı şekilde işlenmiştir. Yazıda Avrupa'nın, Yunanlıların baş döndürücü başarılarını Yunan askeri raporlarından öğrendiklerini ve bu raporlarda Yunanlıların Türk askerlerini cephede perişan ettikleri haberlerine yer verdiğini aktarmaktadır. Gazete yazısında, bu haberlerin asılsız olduğunu haklı çıkarırcasına Türkleri destekleyen sözlere yer vermiştir. Konu ile ilgili -özet olarak- şunlara yer verilmiştir:42

"Bütün Macar basınında, Yunan fantezilerine inanmamaları hususunda toplumu yalnız başımıza inandırmaya çalıştık. Savaşın sonucu bizim bakış açımızı haklı çıkardı. İlk başlardaki bazı Yunan başarılarından sonra Yunan taarruzu zayıfladı, Türkler toparlandı ve bir yıldan itibaren Balkanlar'da ve yakın çevresinde sessizlik hâkim. Nihayet son bir ayda önemli gelişmeler yaşandl. Yunanlılar, Küçük Asya'daki işgal bölgelerinden biri olan Izmir'de ayrı bir devlet kurdular ve bu devletin diğer büyük devletler tarafından tanınmasını istediler. Bununla ilgili olarak Küçük Asya Müdafaa Milli Heyeti Başkanı Dr. Pszaltov Dışişleri Bakanlarının toplantısına katılıp onları ikna etmek için Paris ve Londra'ya gitti. Satılmış yabancı gazeteler, Küçük Asya'da kurulan ve tanınmasını istedikleri Hiristiyan devletin (İzmir) tanınmasını sağlamak için Türklerin işkence yaptıklarına dair hayali masallar uydurdular. Aynı zamanda Yunanlılar, ordularını sürpriz bir șekilde Trakya'dan savunmasız halde olan İstanbul'a aktararak şehri işgal etmek istediler ve Ankara hükümetine karşı paha biçilemez bir üstünlük kurmayı amaçladılar. Doğrusu biz, Yunanlıların İstanbul'u işgal edeceklerine hiç inanmadık ve bu durum çok uzak bir ihtimal olarak durmaktaydı. Çünkü Anadolu'yu işgal eden düşman kuvvetleri büyük bir hızla Küçük Asya'dan gemilerin güvertesi altına geri sürülmüştü. Mustafa Kemal Paşa'nın Türk süvari birlikleri yaklaşıı 3 yıldır Yunan zulmü altında eziyet çeken Türk köylerini Yunan cephelerini yararak yabancı işgalinden kurtardı."

\footnotetext{
41 Melek Çolak, “Türk-Macar İlişkileri ve Macaristan'ın Türk İnkılabına Bakışı (19191938)", 5. Uluslararası Atatürk Kongresi, Bildiriler, C.2, (8-12 Aralık 2003), Ankara, s.1258.

42 "A beteg ember", Magyarság, III. Évi, 202.(510.) Szám, 6 Szerda Szepmtember 1922, s.1.
}

504 | Celal Bayar Üniversitesi Sosyal Bilimler Dergisi - Cilt: 17, Sayı: 3, Eylül 2019 
Yazının devamında, Türklerin mücadelesinin kendileri için de örnek teşkil ettiği belirtilirken, eğer Sevr Antlaşması'nın geçerliliği ortadan kalktıysa Trianon'un, Versay'ın ve Saint Germain anlaşmalarının da yaşam hakkının ortadan kalması gerektiği yazılmıştır.43

Magyarság Gazetesi'nin diğer bir yazısında, Milli Mücadele ve Yunanlılara karşı kazanılan Türk zaferiyle ilgili çarpıcı yorumlar yapılmıștır. "Kemal Musztafa kiverte a görögöket Kis Ázsiából (Mustafa Kemal Yunanlıları Küçük Asya'dan Sürüp Attı) başlıklı yazıda, Mustafa Kemal komutasındaki Türk ordusunun hızlı bir şekilde Yunan kuvvetlerini yenerek kesin bir zafer kazandığı ve Yunan hükümetinin ateşkes istediği yazılmıştır. Yazının devamında, Türklerin bütün güçlerini birleştirerek Yunan işgallerine karşı koydukları ve Mustafa Kemal'in Yunan güçlerini yendiği belirtilmiştir. Türk başarısının dış politika açısından büyük önemi olduğunu vurgulayan gazete, bunun nedeni olarak da müttefik güçlerinin yeni bir barış antlaşması ile meşgul olacakları ve İngiltereFransa arasındaki anlaşmazlığın yeninden söz konusu olacağı şeklinde vermiștir. Gazete, yenilginin ardından Yunan tarafında büyük bir panik havasının hâkim olduğunu ifade etmiş ve Atina'da bir ihtilal çıkma olasılığının yakın olduğunu belirtmiştir. ${ }^{44}$

Gazete, Türklerin başarısının ardından İngiliz ve Fransız tarafının da Mustafa Kemal'e bir ateşkes için teklifte bulunmada istekli olduklarını, fakat Türk tarafının Trakya'nın geri verilmemesi durumunda barıșa pek sıcak bakmadığını belirtmiştir. Ayrıca gazete, Türk ordusunun İzmir'i almalarının çok yakında gerçekleşeceğini ve Türk tayyarelerinin İzmir üstünden şehre bildiriler bıraktığını da yazarken şehirde büyük bir heyecanın yaşandığını da eklemiştir. ${ }^{45}$

Yunanlılara karşı elde edilen zafer sonrasında Antant Devletleri ile Ankara Hükümeti arasındaki yoğun müzakereler dönemi başlamıștı. Türk ordusunun başarılarının ardından Anadolu'da Yunanlıların durumunun çok ağır olduğu söylenirken Yunan birliklerinin İzmir'e çekildiği eklenmiş̦tir. Türklerin Büyük Taarruz ile Yunanlıları kesin bir yenilgiye uğratması ve Mudanya'dan Lozan'a kadar geçen süre zarfındaki gelişmeler yine Macar basınında yakından takip edilmiştir.

\footnotetext{
43 "A beteg ember", s.1.

44 "Kemal Musztafa kiverte a görögöket Kis Ázsiából (Mustafa Kemal Yunanlıları Küçük Asya'dan Sürüp Attı)”, Magyarság, 5 Kedd Szepmtember 1922, s.3.

45 "Kemal Pasa diadalutja Szmirna felé Anglia a francia kelepcében (Mustafa Kemal'in İzmir'e Doğru Zafer Yolu, Fransız Tuzağında İngiltere)”, Magyarság, 10 Vasárnap, Szepmtember 1922, s.2.
} 
Macar basını, Mudanya Antlaşması ile Antant Devletlerinin bağımsız Türk devletini tanıdığını ve Türklerin diplomatik anlamda büyük bir başarı elde ettiğini belirtirken ${ }^{46}$ Mustafa Kemal'in sözlerine yer vererek Onun, Avrupalı ulusları Yunanlıların Anadolu'da acımasız bir politika izlediğine dikkat çekmeye çalıştığını ifade etmiştir. ${ }^{47}$

Macar basınının, Milli Mücadele'nin askeri safhasını ve savaşı kapatan müzakereler dizisini detaylı olarak rapor ettiği görülürken 1919'da gerçekleşen olaylar hakkında çok az bilgi verdiği söylenebilir. Bunun, 1919 döneminin Milli Mücadele'nin hazırlık safhasını kapsaması ve Avrupa basınının gelişmeleri yeni yeni haber alıyor olması gösterilebilir. 1920'de çıkan haberlerin çoğunun diplomatik girişimler ile ilgili olduğu ve bunların içinde en önemli olanların Fransız-İngiliz çatışması, Sevr Barış Antlaşması ve Yunan iç siyasi olayları hakkında olduğu gözlemlenmiştir.48

Askeri olaylar söz konusu olduğunda gazetelerin, ${ }^{49}$ Türk askerinin Ermenilere karşı kazandığı zaferden bahsetmeye değer buldukları ve 192l yılındaki özellikle Yunan saldırılarının başladığı Temmuz'dan itibaren Türk askeri zaferlerini dikkatle takip ettiği görülmüştür. 1922 yılında ise, Milli Mücadele'nin başarısına gidilen yolda günlük raporlar iletilmiştir. Genel olarak bakıldığında, Macar basını Türk Milli Mücadele'sini büyük bir ilgiyle izlemiş ve savaşı sonlandıran diplomatik görüşmeler hakkında detaylı olarak bilgiler vermiștir. Bununla birlikte, yapılan bu haberlerin Paris, Londra, Atina, Viyana, Roma, Milano ve Lozan'dan gelen raporların bakış açısıyla ele alındığı görülmüştür. ${ }^{50}$

\footnotetext{
46 Bíró, a.g.m., s.200-203.

47 “Megegyeztek a Mudániai Előzetes Értekezleten (Ön Mudanya Konferansı'nda Anlaștılar)", Szózat, 6 Octóber 1922, s.3.

48 Bíró, a.g.m., s.203.

49 Ortaç ise, bu gazetelerin haberlerinin yanlı olduğunu yazmıștır. Ona göre, bu gazeteler genel olarak Sevr Anlaşması'nın ruhuna uygun Yunan yanlısı haberler aktardıklarından Anadolu'da yaşananlar hakkında gerçek bilgiler edinmek pek mümkün olmamıştır. bkz. Hilmi Ortaç, "Macar Basınında Kurtuluş Savaşı ve Atatürk", Tarih ve Toplum, C.36, S.215, (Kasım 2001), s.8-14; Yakın zamanlı bir çalışmada ise, Macar basınında Milli Mücadele hakkında yazılar paylaşan bazı gazetelerin, yabancı kaynakların bilgilerine yer vermelerine rağmen Milli Mücadele'den ve Mustafa Kemal'den övgüyle bahsettiklerine ve bazı yazılarında Türklerden "kardeş" olarak söz ederek Türk yanlısı bir duruş sergilediklerine yer verilmiştir. Bkz. Yağcı Aksel, a.g.m., s.53-84.

${ }^{50}$ Bíró, a.g.m., s.204.
}

506 | Celal Bayar Üniversitesi Sosyal Bilimler Dergisi - Cilt: 17, Sayı: 3, Eylül 2019 
Türklerin büyük zaferinin ardından sıra Lozan'daki görüşmelere gelmişti. Lozan'daki görüşmeleri hakkında Macar gazeteleri pek çok haber yapmıştır. Bu haberlerin genel olarak Fransız ve İngiliz kaynaklarına dayandığı görülmektedir. Lozan ile ilgili çıkan bir yazıda Türklerle olan barış görüşmelerinin büyük zorluklarla geçtiği ve Türklerin savaş tazminatı olarak Yunanlıların vermek istediği Karaağaç ile yetinmek istemeyecekleri ve Selanik'i de istedikleri belirtilmiş, görüşmelerin tıkaması durumunda ise Ankara hükümetinin müzakere heyetine görüșmeleri terk etmesi direktifini verdiği yazılmıştır. ${ }^{51}$

Budapesti Hírlap Gazetesi, Lozan görüşmeleriyle ilgili yazısında Türk dostu söylemleriyle dikkat çeken sabık Macar Başbakan Friedrich István'ın sözlerine yer vermiştir. Sabık Başbakan Friedrich yapmış olduğu bir konuşmasında, Yunanlıların İngilizFransız oyununun kurbanları olduğunu ve Türk tarafının da görüşmelere büyük bir güçle geldiğini söylemiştir. ${ }^{52}$

Macar kaynaklarında, kahraman Türk imajı sıklıkla işlenmiștir. Yazllan satırlarda Türklerin kahramanlıklarına geniş yer ayrılmıștır. Macarlara göre, Lozan Antlaşması ve sonuçları Türkler için büyük bir zaferdi ve Mustafa Kemal önderliğinde Türkler büyük bir iș başarmıştı. Turán Dergisi'nde yer alan bir yazıda, "Mustafa Kemal'de cesur bir asker ile düşünceli bir devlet adamının nasıl birleștiğini görüşüyoruz" denirken,53 Mustafa Kemal'in her șeyden önce vatanını, Türkiye'yi özgürlügüne kavuşturduğu ifade edilmiştir. Sevr Antlaşması ile Türklüğe emperyalist bir hançer vurulmak istediğinde Mustafa Kemal o zaman büyüklügünü göstermiştir. ${ }^{54}$

Ünlü Osmanlı tarihçisi ve Macar Paleograf Fekete, Türk milletinin bağımsızlığına inanan yegâne insanın Mustafa Kemal olduğunu söylerken Onun, Anadolu'ya geçerken imkânsızı başarmak amacıyla İstanbul'dan ayrıldığını söylemiştir. Yine Fekete, " $A z$ új Törökország(Yeni Türkiye)” adlı eserinde Milli Mücadele’yi değerlendirirken Mustafa Kemal'in Anadolu'ya geçtiğinde halkı kendi etrafında başarılı şekilde örgütlediğini ve İstanbul'dan kaçarak Milli

\footnotetext{
51 "Háborús hangulat a lausennei konferencián (Lozan Konferansı'nda Savaş Atmosferi)", Az Est, XIV. Évfolyam, 118. Szám, Május 27, Budapest 1923, s.1.

52 "Magyarország és a lausennei konferencia (Macaristan ve Lozan Konferansı)", Budapesti Hírlap, 6 December 1922, s.6.

53 Medriczky, a.g.m., s.126.

54 Horváth Béla, "Kemál Atatürk", Új Idők, XLIV. Évfolyam, 47. Szám, 20 November 1930, s.62-63.
} 
Mücadele'ye katılan deneyimli ve vatansever subaylarla büyük bir direniş başlattığını yazmıştır. Bu direniş hareketinin sonucunda Türk ordusunun kazandığı büyük zaferin tüm dünyada hayretle izlendiğini ve sürpriz olarak karşılandığını söyleyen Fekete, Macar halkının da Türk zaferinin haberini büyük bir sevinçle karşıladığını yazmıştır. ${ }^{55}$ Atatürk'ün doğumunun 100. ylldönümünde bir konuşma gerçekleştiren ünlü Türkolog Hazai de, Atatürk'ün yaşam döngüsünün, bir dünya imparatorluğu olan Osmanlı Devleti'nin, Milli Mücadele'nin ardından Türkiye Cumhuriyeti'ne kesin olarak dönüşümüyle karşı karşıya kaldığı yoğun olaylar silsilesinin bir yansıması olarak aktarmıștır. Atatürk'ün her türlü zorluğa rağmen hayatını riske atarak emellerinden vazgeçmediğini vurgulayan Hazai, yalnızca genç Sovyet Devleti tarafından desteklenen Milli Mücadele'nin, 1922'de tam bir zaferle sona erdiğini ve bu zaferle Türklerin, Birinci Dünya Savaşı galiplerinin dikte ettiği Sevr Antlaşması'nı yok saydığını belirtmiştir. ${ }^{56}$

Macar Turancilarından Alajos Paikert de, Turán Dergisi'nde yayınlanan bir yazısında Mustafa Kemal'den ve Türk zaferinden övgü dolu sözlerle bahsetmiştir. Paikert yazısında; "Mustafa Kemal'in kazanmış olduğu büyük zaferin ardından Türk milletinin eski parlak günlerinin tekrar yükseldiğini, eziyet çekmiş, aşağılanmışs soylu Türk milletinin uzun bir rüyadan uyandığını hissediyoruz" şeklinde bir ifadeye yer vermiştir. Ona göre, Mustafa Kemal de modern bir Turan adamıdır. Aynı zamanda Mustafa Kemal, Türk milletinin ruhunu ve kadim Turani dehasını anlamıştı ve buna göre davranmıştı. 0 , milletini utanç verici esaretten kurtarmıştı. Parlak zaferlerinden sonra zar zor dinlenmiş, okullar kurmuş, yollar ve demiryolları inşa etmiş, telsiz istasyonları, fabrikalar, sulama kanalları ve tesisler kurmuştu. Yani, ülkesini sil baştan yeniden inşa etmişti. Yazısının devamında Macar Turancılarının Türklere ve Mustafa Kemal'e karşı duyduğu sevgiyi ve sempatiyi anlamak mümkündür: ${ }^{57}$

"Seni kalpten selamliyoruz şanlı ve muzaffer başkumandan ve güçlü devlet adamı. Bugün hüzünlü ve üzücü köleliğimizi sizinle hissediyoruz. Sizlerin kahramanca örneğinden güç allyoruz ve

\footnotetext{
55 Fekete Lajos, Az új Törökország (Yeni Türkiye), Budapest 1939, s.1-18.

56 György Hazai, “Musztafa Kemál Atatürk”, Világtörténet, 2. Szám, 1983, s.67-69.

57 Alajos Paikert, "Musztafa Kemál pasa (Mustafa Kemal Paşa)", Turán, III.IV Évnegyed, 25. Szám, 1922, s.138-139.
} 
umudumuz kırllmıyor. Çünkü biliyoruz ki karanlı geceden sonra parlayan bereketli bir gün gelecek."

\section{Macar Elçilik Raporlarında Milli Mücadele}

Macar basınının yanı sıra Macar devlet adamlarının da dikkatini Anadolu'daki savaşa çevirdiği süreçte Turan Cemiyeti'nin, Anadolu'daki Milli Mücadele'nin yanında yer alarak Türk tezini desteklemesi, Macar komuoyununda önemli ölçüde bir Türk ilgisinin oluşmasına neden olmuștu. ${ }^{58}$

Macarların Milli Mücadele'ye sempati ile baktığı bu dönemde Ankara Hükümeti ile Macarlar arasında 1921 yılı itibari ile bazı temaslar gerçekleşmişti. Türklerin Yunanlılara karşı elde ettiği zaferler, Macar diplomatların Ankara Hükümeti ile temas kurmasında etkili olmuştur. İki kükümet arasındaki ilk temaslarda herhangi bir devletin arabulucuk girişiminden ziyade, konumları itibari ile İtalya ve Bulgaristan ön plana çıkmıştır.59 İtalya'nın, hem Ankara Hükümeti'nin hem de Macaristan'ın Avrupa'da dış temsilciliğinin bulunduğu bir merkez olması nedeniyle ilk diplomatik temasların burada gerçekleştiği görülmüştür. ${ }^{60}$

Milli Mücadele döneminde Ankara Hükümeti ile resmi temas kurmanın yollarını arayan Macarlar, Sofya ve Roma gibi merkezlerdeki Ankara Hükümeti temsilcileri ile görüşmeler gerçekleştirmiş ve görüşmelerle ilgili raporlar yazarak Macaristan Dışişleri Bakanlığı'na göndermişlerdir. Bu raporlarda Türklerin Milli Mücadele ile kazandığı büyük başarılardan da söz edilmiştir.61

Milli Mücadele'nin başarıyla sonuçlanmasının ardından Roma'da Türk ve Macar diplomatlar arasında çok sayıda karşılıklı ziyaretin gerçekleştiği görülmektedir. Bu temaslardan birinde Türk zaferiyle ilgili olarak Ankara Hükümeti'nin Misyon Sekreteri Agah Bey ile Macar Maslahatgüzarı Márffy arasında 18 Eylül 1922

\footnotetext{
58 Saral, a.g.e., s.141.

59 Müjdat Karagülmez, Atatürk Dönemi'nde Türkiye'deki Macar Elçileri ve Türk-Macar Siyasi İlişkileri (1923-1938), Muğla Üniversitesi Sosyal Bilimler Enstitüsü, Muğla 2018, s.60-61.

60 Saral, a.g.e.,s.142.

61 Bu raporlar Macar Milli Arşivi'nin Dışişleri Bakanlığı Kataloglarındaki K 63 kodlu fonunda yer almaktadır. Bkz. Magyar Külügyminisztérium Levéltára (Dışişleri Bakanlı̆̆ı Arşivi) (1918-1945), C.1, Der. Nagy Ferenc, Budapeşte 2003; Magyar Külügyminisztérium Levéltára(Dışişleri Bakanlığı Arşivi) (1918-1945), C.2, Der. Nagy Ferenc, Budapește 2007.
} 
tarihinde bir görüşme gerçekleşmiştir. Bu görüşmede Márffy, Macar hükümeti adına Milli Mücadele'nin başarıya ulaşmasından dolayı Türk hükümetine candan selamlarını iletmiștir. ${ }^{62}$ Márffy'nin, Türk askerlerinin cephede kazandığı büyük başarıları hususunda Türk tarafına tebriklerini iletmesinin ardından Roma'daki Ankara Hükümeti temsilcisi Celaleddin Bey, hükümetinden aldığı talimat doğrultusunda 14 Ekim 1922 tarihinde Macaristan'ın Roma elçisi Nemes'e bir ziyarette bulunmuştur. Celaleddin Bey bu görüşmede Macar Hükümeti'nin Türk zaferiyle ilgili tebriklerinin, Türkiye Büyük Millet Meclisi'nde büyük bir etki yarattığını ve bunun için Türk Hükümeti'nin kendilerine teşekkürlerini ilettiğini söylemiştir.63

Márffy, 14 Ekim 1922'de Celaleddin Bey ile görüşmesinden sonra yakın zamanda toplanacak olan Lozan Konferansı'yla ilgili olarak Macar Dışişleri Bakanlığı'na bir telgraf göndermiştir. Márffy'nin bu konudaki düşünceleri ilgi çekicidir: 64

"Bugün Celaleddin Bey ile bir görüşme gerçekleștirdik ve ona göre (Celaleddin Bey), Türkler Batı Trakya'da bir halk oylamasının olmasını ümit ediyor. Bu konuda Bulgaristan'a güvenmiyorlar. Daha ziyade cephane ve para yardımı aldıkları Sovyet Rusya'ya güveniyorlar. Genel olarak (Celaleddin Bey) Ankara'daki Büyük Millet Meclisi hakkında gururla ve iddialı konuştu. Sözlerinden anlaşıldığı kadarıyla Türkler ile olacak barış görüşmeleri çok kolay olmayacak."

Márffy, Ankara Hükümeti temsilcileri ile görüşmesinin hemen öncesinde Roma'da bulunan İstanbul hükümeti temsilcisi ile de Milli Mücade'ye dair bir görüşme gerçekleştirmiştir. Márffy, bu konula ilgili 20 Eylül 1922 tarihinde Macar Dışişleri Bakanlığı'na ilginç bir rapor göndermiştir. Márffy raporunda, Roma'daki İstanbul Hükümeti temsilcisi Osman Nizam Paşa ile bir görüşme gerçekleştirdiğini yazmıştır. İkili arasında gerçekleşen görüşmede Márffy, Türk zaferi hakkında Osman Nizam Paşa'ya tebriklerini iletirken, Osman Nizam Paşa'nın sanki bir Ankara Hükümeti temsilcisi gibi kendini dinlediğini aktarmıştır. Ayrıca Osman Nizam Paşa'nın, Türk zaferinin

\footnotetext{
62 MOL (Magyar Országos Levéltár (Macar Milli Arşivi), K 63, 287. bağ, 32/1, 32. başlık, Macar Maslahatgüzarının Roma'daki Türk Misyon Sekreteri ile yapmış olduğu görüşme ile ilgili 18 Eylül 1922 tarihli rapor.

63 MOL, K 63, 287. bağ, 32/1, 32. başlık, Macar elçi Nemes'ten Macaristan Dıșişleri Bakanlı̆̆ı'na gönderilen 14 Ekim 1922 tarihli ve 277-pol sayılı rapor.

${ }^{64}$ Karagülmez, a.g.e., s.67.
} 
barış anlaşmalarına karşı vurulan ilk büyük darbe olduğunu ifade ettiğini de aktarmıştır.65

Macarlara göre Türkiye, I. Dünya Savașı'ndan sonra bağımsızlığı için büyük çaba sarf eden ve Lozan Antlaşması gibi bir anlaşma ile tekrar özgürlügüne kavuşan ve vatanını düşmanlardan temizleyebilen en önemli örnekti.66 Lozan Konferansı'nda resmi kanallar vasıtasıyla Türk yetkililerle temas kuramayan Macar Hükümeti, 1923 yılının Ocak ayı itibariyle Jenő Ruszkay adında bir Kurmay Yüzbaşıyı Ticaret Atașesi sıfatıyla Anadolu'ya göndererek, Türklerle temasa geçmiştir. ${ }^{67}$ Ruszkay'ın Anadolu'daki temaslarının ardından Türk ve Macar hükümetleri arasında 18 Aralık 1923 tarihinde bir dostluk anlaşması imzalanmıștır. Böylece, Milli Mücadele döneminde Türklere büyük destek veren Macarlar ile Türkiye Cumhuriyeti arasında Mondros sonrasında kesilen resmi ilișkiler 5 yıla yakın bir aradan sonra yeniden tesis edilmiștir. ${ }^{68}$

\section{Sonuç}

Mondros Mütarekesi'nin imzalanmasından sonra Anadolu'nun Antant Devletleri ve Yunanistan tarafından işgal edilmesi, Türk halkında büyük bir direniş hareketinin başlamasına neden olmuştur. İşgallere tepki olarak Mustafa Kemal'in Türk halkını örgütleyerek Anadolu'yu kurtarma çabası Macarların dikkatini çekmiștir. Macarlar, Türk direnişinin adeta Avrupa'daki savunucusu olmuşlar ve basın yayın yoluyla kardeș olarak gördükleri Türklerin yardımına koşmuşlardır. 1910 yılında kurulan Turán Cemiyeti, çıkarmış olduğu Turán Dergisi'nde neşrettiği yazılarda Anadolu'daki işgallerin haksız olduğunu söyleyerek Avrupa kamuoyunu bu konuda ikna etmeye çalışmıştır. Macarlara göre, Türkler Mustafa Kemal'in sayesinde derin bir uykudan uyanarak yurdunu savunmak için büyük

\footnotetext{
65 MOL, K 63, 287. bağ, 32/1, 32. başlık, İstanbul Hükümeti büyükelçisi ile Macar Maslahatgüzar arasında Barış Anlaşmaları hakkında gerçekleşen 20 Eylül 1922 tarihli ve 257-pol sayılı rapor.

66 Ágnes Tóth, Magyar lendkerekek az új Törökország gépezetében, avagy gazdasági és kulturális együttmúködés Törökország és Magyarország között az atatürki aranykor időszakában (Yeni Türkiye'nin Çarkındaki Macar Dişliler Ya da Atatürk'ün Altın Zamanında Türkiye ile Macaristan Arasındaki İktisadî ve Kültürel İşbirliği), Grotius E-Könyvtár. 2009, s.16.

67 Saral, a.g.e., s.151.

68 "Barátsagi szerződés Magyarország és Törökország között (Macaristan ve Türkiye Arasında Dostluk Anlaşması)", Magyar Törvények 1924 évi Törvénycikkek (Macar Yasaları 1924 Yılı Yasa Maddeleri, (1924), Codex Kiadás, Budapest, s.170-171.
} 
bir özveri ile savaşmaya başlamıștı ve bu görev Mustafa Kemal'in kaderinde yazılıydı. Mustafa Kemal'i büyük bir devlet adamı ve asker olarak gören Macarlar, Türklerin Yunanlılara karşı elde ettikleri zaferi büyük bir sevinç ile karşılamışlardır. Macar basını da çıkarmış oldukları gazetelerle Türklere destek olmuş ve Milli Mücadele'yi ayrıntılı olarak sayfalarına taşımışlardır. Türk zaferi, Macar Hükümeti'nde de sevinçle karşılanmıştır. Macar elçilik raporlarında da Milli Mücadele'ye yer ayrılmış ve Türk zaferinin ardından Roma'daki Macar Elçiliği temsilcileri Ankara Hükümeti temsilcileriyle görüşmeler gerçekleştirmiştir. Bu görüşmelerde, Milli Mücadele'nin zaferle sonuçlanmasının Macar Hükümeti'nce sevinçle karşılandığı ve Macar Hükümeti'nin bu başarıdan dolayı Ankara Hükümeti'ni tebrik ettiği ifade edilmiştir.

\section{Kaynakça}

“A Beteg Ember (Hasta Adam)”, Magyarság, Iii. Évi, 202.(510.) Szám, 6 Szerda Szepmtember 1922, S.1.

"Háborús Hangulat A Lausennei Konferencián (Lozan Konferansı'nda Savaş Atmosferi)", Az Est, Xiv. Évfolyam, 118. Szám, Május 27, Budapest 1923, S.1.

Baştav Şerif, "Tarihte Türk-Macar Münasebetleri Ve Macar-Türk Akrabalığı", Tarih Ve Toplum, S.215, (Kasım 2001), S.59-65.

Bíró Gábor, “A Török Függetlenségi Háború A Magyar Sajtó Tükrében (Macar Basını Işığında Türk Bağımsızlık Mücadelesi)," Acta Universitatis Szegediensis, Acta Historica, 126. Tom, 2007, S.195204.

Çolak Melek, "Macaristan'da Türkoloji, Turancılık Ve Türk Dünyası (Xıx. Yüzyıldan Xx. Yüzyıla)", 15. Uluslararası Türk Dünyası Sosyal Bilimler Kongresi, Tebliğler Kitabı, (Moldova 2017), S.461-465.

Çolak Melek, "Macar Turancıları Ve Atatürk(Macar Kaynaklarına Göre)", Türk Yurdu, C.31, S.21, (Ekim 2010), S.77-87.

Çolak Melek, “Türk-Macar İlişkileri Ve Macaristan'ın Türk İnkılabına Bakışı (1919-1938)", 5. Uluslararası Atatürk Kongresi, Bildiriler, C.2, 8-12 (Aralık 2003), Ankara, S.1253-1266.

Çolak Melek, "Atatürk Döneminde Kültürel, Siyasi Ve Ekonomik Bakımdan Türk-Macar İlişkileri (1919-1938)", Muğla Üniversitesi Sbe Dergisi, C.1, S.2, (Güz 2000), S.61-72.

Demirkan Tarı, Macar Turancıları, Tarih Vakfı Yurt Yayınları, İstanbul 2000. 
Dilan H. Berke, Siyasi Tarih 1914-1939, Alfa Yayınları, İstanbul 1998.

Fekete Lajos, Az Új Törökország (Yeni Türkiye), Budapest 1939.

Flesch István, Atatürk És Kora, Musztafa Kemál Atatürk Függetlenségi Háborúja És Kormányzása (Atatürk Ve Dönemi, Mustafa Kemal'in Bağımsızlık Mücadelesi Ve Yönetimi), Corvina Kiadó, 2004.

Fodor Gábor, "Macar Gözüyle Osmanlı İmparatorluğu Ve Türkiye (1850-1940)”, Güney-Doğu Araștırmaları Dergisi, Y.2014-1, S.25, S.79-90.

Hazaı György, "Musztafa Kemál Atatürk", Világtörténet, 2. Szám, 1983, S.67-69.

Hermann Róbert, Joó András, Mészáros Kálman, Seres István, Török Menedékjogot Kapott Magyar Emigránsok Rövid Életrajzi Összefoglalója (Türkiye'de Kendilerine Siğınma Hakkın Tanınan Macar Mültecilerinin Hayatlarından Özetler), Türk-Macar Dostluk Derneği, 2010.

Horvát Béla, "A Turáni Eszme És A Török-Magyar Kapcsolatok Az Utolsó Évszázadban (Turan Düşüncesi Ve Son Yüzyllda TürkMacar İlişkileri", Turán, Xxii. Évfolyam, 6. Szám, 1939, S.119-122.

Horvát Béla, "Kemál Atatürk", Új Idốk, Xliv. Évfolyam, 47. Szám, 20 November 1930, S.61-63.

Jaeschke Gotthard, Kurtuluş Savaşı İle İlgili İngiliz Belgeleri, Türk Tarih Kurumu, Ankara 2011.

Kakuk Zsuzsa, "Türk Kültür Etkisinin Macar Dilindeki Yansımaları", Ix. Türk Tarih Kongresi, Ttk, C. Iı, (21-25 Eylül 1981), Ankara 1989, S.1223-1225.

Kelemen Mikes, Osmanlı'da Bir Macar Konuk Prens Rákóczi Ve Kelemen Mikes'in Türkiye Mektupları, Çev. Edit Tasnadi, Aksoy Yayıncllık, İstanbul 1999.

"Kemal Musztafa Kiverte A Görögöket Kis Ázsiából (Mustafa Kemal Yunanlıları Küçük Asya'dan Sürüp Attı)", Magyarság, 5 Kedd Szepmtember 1922, S.3.

"Kemal Pasa Diadalutja Szmirna Felé, Anglia A Francia Kelepcében

(Mustafa Kemal'in İzmir'e Doğru Zafer Yolu, Fransız Tuzağında İngiltere)", Magyarság, 10 Vasárnap Szepmtember 1922, S.2.

Magyar Külügyminisztérium Levéltára (Dışişleri Bakanlığı Arşivi) (1918-1945), Cilt.1, Der. Nagy Ferenc, Budapeşte 2003.

Magyar Külügyminisztérium Levéltára (Dışşşleri Bakanlığı Arşivi) (1918-1945), Cilt.2, Der. Nagy Ferenc Budapește 2007.

"Magyarország És A Lausennei Konferencia (Macaristan Ve Lozan Konferansı)", Budapesti Hírlap, 6 December 1922, S.6. 
"Barátsagi Szerződés Magyarország És Törökország Között (Macaristan Ve Türkiye Arasında Dostluk Anlaşması)", Magyar Törvények 1924 Évi Törvénycikkek (Macar Yasaları 1924 Yılı Yasa Maddeleri, (1924), Codex Kiadás, Budapest, S.170-171.

Medriczky Andor, "Kemal Atatürk A Had Vezér Az Államférfi És Az Ember (Bir Kamutan, Devlet Adamı Ve İnsan Olarak Kemal Atatürk", Turán 1937-38, Vlı-X.Szám., Xx-Xxı. Évfolyam, S.121138.

"Megegyeztek A Mudániai Előzetes Értekezleten (Ön Mudanya Konferansı'nda Anlaştılar)", Szózat, 6 Octóber 1922, S.3.

Müjdat Karagülmez, Atatürk Dönemi'nde Türkiye'deki Macar Elçileri Ve Türk-Macar Siyasi İlişkileri (1923-1938), Muğla Üniversitesi Sosyal Bilimler Enstitüsü, Muğla 2018.

Namal Yücel, Türk-Macar İlişkileri, İskenderiye Yayınları, İstanbul 2009.

Nesrin Gürkan, "Tarihte Macar Misafirlerimiz", 2023, S.59, Haziran 2006, S.52-57.

Németh Gyula, "Törökök És Magyarok (Türkler Ve Macarlar)", Törörök És Magyarok I, Budapest 1990, S.24-26.

Nyírı Mária, "Türklügün Bir Kolu Olarak Macarlar Veya Türk-Macar Kardeşliği-Akrabalığı Ve Tarihsel İlişkiler Üzerine", Çeşitli Türk Toplumları Arasındaki Dil Ve Kültür Bağı Sempozyumu, Kıbrıs Araştırma Ve Yayın Merkezi, (5-6 Ekim 1990), Lefkoşa, S.1-25.

Ortaç Hilmi, "Macar Basınında Kurtuluş Savaşı Ve Atatürk", Tarih Ve Toplum, C. 36, S.215, (Kasim 2001), S.8-14.

Özkaya Yücel, "Mustafa Kemal Paşa Anadolu'da", Mücadele TarihiMakaleler-, Haz. Berna Türkdoğan, Atatürk Araştırma Merkezi.

Paikert Alajos, "Musztafa Kemál Pasa (Mustafa Kemal Paşa)", Turán, Ill. Iv Évnegyed, 25. Szám, 1922, S.138-139.

Palotás Zoltán, A Trianoni Határok (Trianon Sinırları), Interedition, Budapest 1990.

Saral Emre, Türkiye-Macaristan İlişkileri (1920-1945), Basılmamıș Doktora Tezi, Hacettepe Üniversitesi Atatürk İlke Ve İnkılapları Enstitüsü, Ankara 2016.

Sofuoğlu Ebubekir, "Abdülmecit Ve Macar Mülteciler", Tarih Ve Toplum, S.215, (Kasım 2001), S.279-302.

Tasnádı Edit, "18.-19. Yüzyılda Osmanlı'da Macar Mülteciler”, Tarih Ve Toplum, C.36, S.215, (Kasım 2001), S.327-332.

514 | Celal Bayar Üniversitesi Sosyal Bilimler Dergisi - Cilt: 17, Sayı: 3, Eylül 2019 
Tóth Ágnes, Magyar Lendkerekek Az Új Törökország Gépezetében, Avagy Gazdasági És Kulturális Együttműködés Törökország És Magyarország Között Az Atatürki Aranykor İdőszakában (Yeni Türkiye'nin Çarkındaki Macar Dişliler Ya Da Atatürk'ün Altın Zamanında Türkiye İle Macaristan Arasındaki İktisadî Ve Kültürel İşbirliği), Grotius E-Könyvtár. 2009.

"Török-Magyar Barátság (Türk-Macar Dostluğu)", Magyar Külpolitika, Xıv. Évfolyam, 10. Szám, 1933-Október, Budapest, S.11.

“Török Barátaink (Türk Kardeşlerimiz)", Budapesti Hírlap, Xlxılı. Évfolyam, 186. Szám, 17 Augusztus 1928, Budapest, S.1.

Türk-Macar Münasebetleri Ișığı Altında Iı. Ferenc Rákóczi Ve Macar Mülteciler Sempozyumu (31 Mayıs-3 Haziran 1976), İstanbul Üniversitesi Edebiyat Fakültesi, İstanbul-1976.

Vukovári Gábor, "A Török Külpolitika Alapjai És Változásai (Türk Dış Politikasının Temelleri Ve Değişimleri)", Külügyi Szemle, 2. Évfolyam, 4. Szám-1975, S.39-55.

Yağcı Sevgi Can Aksel, "Macar Basınında Türkiye: “Küçük Asya”Nın Büyük Direnişi (1920-1923)", Illef Dergisi, 2018, 5(2), Sonbahar, S.53-84.

Zoltán Egeseri, "A Török Nemzetépítés Atatürk Korában (Atatürk Döneminde Türk Ulus İnşası)" Világtörténet-Tanulmáynok, (2013):1, S.125-144. 


\section{Ekler}

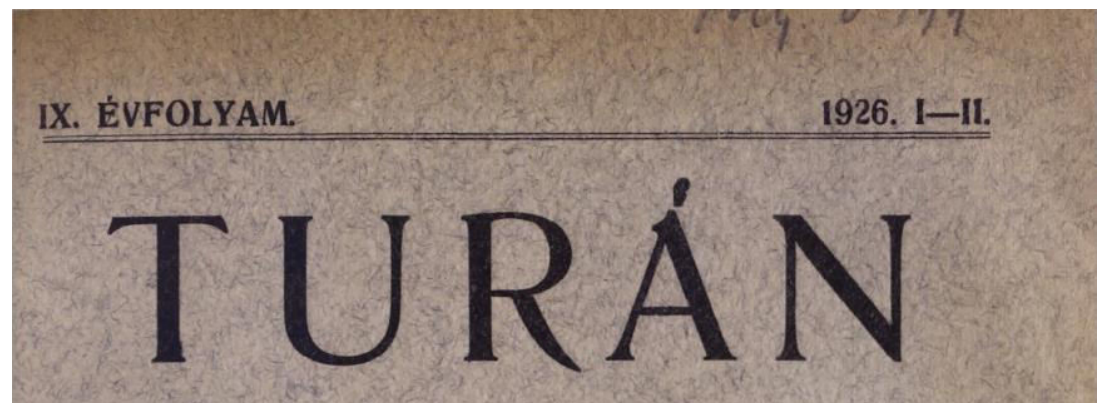

A TURÁNI TÁRSASÁG FOLYÓIRATA.

S Z E R E S Z T Ó S É G:

PEKAR GYULA

FÓSZERKESZTÓ

CHOLNOKY JENÕ

BAN ALADAR

FELELOS SZERKESZTÓ

TARTALOM: Marki Sándor: A mongolok Magyarországon. - Cholnoky Jenö: A rizstermelés jelentősége az ember müvelödéstörténetében. - Bán Aladár: Részlet a Kalevipoegból. - Móricz Péter: Törökország jelenlegi világpolitikai helyzete. - Moravcsik Gyula: Török népvándorlás az orosz síkságon. - Kisebb közlemények. - Irodalom. - Hirek. - Társasági ügyek.

Ez a szám megjelent 1926, június 29-én.

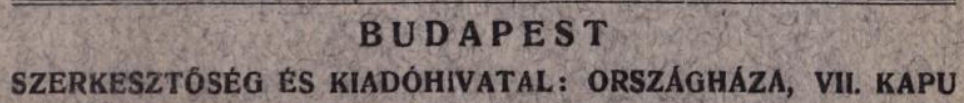

A. kiadásért felelös: Dr. BAN ALADAR.

516 | Celal Bayar Üniversitesi Sosyal Bilimler Dergisi - Cilt: 17, Sayı: 3, Eylül 2019 
EK-1. 1926 yllına ait Turán dergisinin kapağı.

\section{Kemál Atatürk a hadvezér, az állam- férfi és az ember.}

Irta: Medriczky Andor $d r$.

Éppen akkor, amidön a kassai dóm tornyában megkondultak a harangok, hogy hirdessék az egész világnak: Rákóczi sirja hazatért az anyaországhoz, - ugyanakkor messze, a Márvány-tenger partján a legszebb szultáni palotában: a Dolma Bagcseban már kiteritve feküdt a török nemzet legnagyobb tia: a szöke, kékszemü, államépitö Kemal Atatürk. A magyar örömújjongásban nagyon sokan gondoltunk meghatottan és megdöbbenve a török testvérnemzet pótolhatatlan veszteségére. Rákóczi harangja is összekapcsolta ezen a napon a török nemzetet a magyarral, hiszen nem felejtettük el, hogy a bujdosó Fejedelemnek éppen az a testvéri Törökország adott otthont a Márványtenger partjain fekvö Rodostó Tekirdag városában, ott szenderült el és éppen a Dolma Bagcse közelében a galatai Szt. Benedek templomban pihent 170 évig a magyar nemzet nagyságos Fejedelme.

Bizonyára voltak magyarok Istambulban, akik azon az emlékezetes november 11 -én az éterhullámokon át közvetítették a kassai harangok zúgását és a nyitott ablakokból néhány hangfoszlány meg-megsímogatta Kemal Atatürk viaszsárga, kihült arcát is, amelyen elsimultak már, boldog megbékélésben az örökké fáradhatatlan államférfi életének ezer apró és nagy eseményei által szántott barázdák.

Kemal Atatürk elvesztésének súlyát talán semmi sem jellemzi jobban, mint az, hogy halottas ágyánál egy képviselö barátja föbelötte magát. Hangos zokogások verték fel az utcák csendjét. Emberek tömege pusztult el, vagy sebesült meg a temetési szertartások közepette és a török kormány 2 millió pengöt fordított arra, hogy a török köztársaság meg-

EK-2. Andor Medriczky, "Kemal Atatürk a had vezér az államférfi és az ember (Bir Kamutan, Devlet adamı ve İnsan Olarak Kemal Atatürk)", Turán, 1937-38, VII-X.szám., XX-XXI. Évfolyam. 


\section{Musztafa Kemál pasa. \\ Irta : Paikert Alajos.}

A török nemzet régi, fényes dicsősége ismét felvirrad Musztafa Kemál pasa gyôzedelmes haditetteivel. Érezzük azt a friss és biztató szellôt, amely Kis=Ázsiából felènk árad. Érezzük azt, hogy az egy agyonzaklatott, megkinzott, megalázott, nemes nemzet felébredése hosszú, keserves álmából. Érezzük azt, hogy ez a hajdan oly erôs, lovagias, oly nemes gondolkozású testvér. nép, amelyröl a legújabb korig szabad volt a legutolsóknak is becsmériōleg nyilatkozni, eljutott méltánytalan megaláztatása leg. mélyebb fokáig. Ekkor összerázkódott, reáeszmélt a valóságra, reátalált önmagára, reátalált önérzetére és hatalmára és összes szedve minden erejét, méltó haragjában lerázta magáról eddigi kinzóit és szipolyozóit, elūzte, kiverte azokat dicso̊séges har: cokban hazájából.

Jól tette; szent kötelessége ez minden önérzetes, férfias nemzetnek.

Az a nemzet, amely elhagyja hagyományait, amely meg. engedi, hogy idegenek gúnyt üzzenek legszentebb érzéseibỏi, amely tủri, hogy saját derék fiait és leányait idegenek szorítsák ki apáik örökéből, amelynek magasabb aspirációi nincsenek, az méltán veszti el a többi nemzetek tiszteletét és becsülésèt.

A török nemzet ime önerejéböl felszabaditotta magát, példát mutatott az elnyomott, megalázott és rabságban tartott nem= zeteknek, intó példát pedig a gyōzelmükben elbizakodottaknak, hogy - eddig és ne tovább !

Musztafa Kemál pasa megértette a török nemzeti lelket, megértette az ôsi turảni géniuszt és eszerint cselekedett - epo: châlis sikerrel. Kemál pasa, a dicsőséges hadvezér azonban mo: dern turáni államférfiú is, $\hat{O}$ nem irt és pusztit; ó felszabaditja

\section{EK-3. Alajos Paikert, "Musztafa Kemál pasa (Mustafa Kemal Paşa)", Turán, III.IV Évnegyed, 25. Szám, 1922.}

